\title{
Analisa Kuat Lentur Beton Aspal pada Perkerasan Lentur Jalan
}

\author{
Muhammad Latif 1, Wardana Galih Pamungkas2, Bambang Purnijanto3 \\ Universitas Semarang, Indonesia
}

DOI: http://dx.doi.org/10.26623/teknika.v14i2.kodeartikel

\section{Info Artikel}

Sejarah Artikel:

Disubmit 15-07-2021

Publish 30-12-2021

\section{Keywords:}

asphalt waste; concrete flexural strength

\begin{abstract}
Abstrak
Kurang dimanfaatkannya limbah aspal di Laboratorium Transportasi menyebabkan pencemaran lingkungan. Dalam penelitian ini limbah aspal tersebut digunakan sebagai bahan penambahan dalam campuran beton yang merupakan salah satu solusi mengatasi masalah limbah aspal. Meneliti lebih mendetail terkait manfaat limbah aspal untuk meningkatkan kuat lentur beton. Prosentase campuran limbah aspal sebesar 10\%, 12\%, dan 15\% dilihat dari kuat lentur. Metode Eskperimen memakai benda uji berupa balok beton berukuran $60 \mathrm{~cm} \times 15 \mathrm{~cm} \times 15 \mathrm{~cm}$ yang ditekan pada umur yang telah di tentukan.. Setiap jenis sampel terdiri 3 benda uji dengan berat campuran yang berbeda., sehingga keseluruhan benda uji berjumlah 12 buah. Hasil pengujian kuat lentur diperoleh Beton normal pada pada hasil pengujian kuat lentur nilainya $12 \mathrm{Mpa}$, Pada berat limbah aspal $10 \%$ nilai kuat lentur didapatkan 13,30 Mpa. Berat limbah aspal 12\% nilai kuat lentur senilai 7,60 Mpa. Dan Berat limbah aspal $15 \%$ nilai kuat lentur $=5,00 \mathrm{Mpa}$
\end{abstract}

Abstract

The underutilization of asphalt waste in the Transportation Laboratory causes environmental pollution. In this research, the asphalt waste is used as an additional material in the concrete mixture which is one solution to the problem of asphalt waste. Researching in more detail the benefits of asphalt waste to increase the flexural strength of concrete. The percentage of asphalt waste mixture is $10 \%, 12 \%$, and $15 \%$ in terms of flexural strength. The experimental method uses a test object in the form of a concrete block measuring $60 \mathrm{~cm} \times 15 \mathrm{~cm} \times 15 \mathrm{~cm}$ which is pressed at a predetermined age. Each type of sample consists of 3 specimens with different mixed weights, so that the total number of test objects is 12. The results of the flexural strength test were obtained by normal concrete on the results of the flexural strength test the value was $12 \mathrm{Mpa}$, at $10 \%$ asphalt waste weight the flexural strength value obtained 13.30 Mpa. Asphalt waste weight $12 \%$, the flexural strength value is 7.60 Mpa. And the weight of asphalt waste is $15 \%$, the flexural strength value $=5.00 \mathrm{Mpa}$ Key Words : asphalt waste, concrete flexural strength

Alamat Korespondensi: p-ISSN 1410-4202

E-mail: muhammadlatif@Usm.ac.id 


\section{PENDAHULUAN}

Jalan yang menggunakan bahan beton harus memiliki kualitas bahan yang baik dan dipengaruhi oleh kuat lentur beton. Untuk meningkatkan kuat lentur beton pada jalan, maka perlu dipelajari lebih dalam mengenai sifat dan karakteristik materialnya (Mulyono .2014). Agar hasil pembuatan struktur beton menunjukkan hasil yang memuaskan, maka diperlukan 2 (dua) syarat, yaitu kekuatan tekan dan kemudahan pengerjaan (Asrullah .2019). Untuk menghasilkan beton berkualitas maka faktor air terhadap semen haruslah kecil. Hal tersebut dapat menyebabkan kesulitan dalam pengerjaan. Penelitian sebelumnya memamakai serat nanas untuk bahan tambah dalam pencampuran beton. (Yasa dan Wati. 2015). Juga pemanfaatan limbah bulu ayam untuk pembuatan sampel kuat tekan beton (Akmalia dan Izati.2018). Kurang dimanfaatkannya limbah aspal di Laboratorium Transportasi Universitas Semarang sebagai bahan sisa pengerjaan praktikum jalan serta limbah aspal dari penelitian tugas akhir mahasiswa menghasilkan limbah aspal yang banyak mengganggu kebersihan lingkungan Fakultas Teknik, khususnya daerah sekitar Laboratorium Transportasi. Dalam penelitian ini limbah aspal tersebut digunakan sebagai bahan penambahan dalam campuran beton yang merupakan salah satu solusi mengatasi limbah aspal. Meneliti lebih detail terkait manfaat limbah aspal untuk meningkatkan kuat lentur beton. Prosentase campuran limbah aspal yang digunakan sebesar $10 \%, 12 \%$, dan $15 \%$ dari total berat campuran beton. Penelitian ini benda uji berupa balok beton berukuran $60 \mathrm{~cm} \times 15 \mathrm{~cm} \times 15 \mathrm{~cm}$ yang diuji kuat lenturnya pada umur 28 hari (Leonardus,dkk.2019). Untuk penambahan 10\% limbah aspal ada 3 (tiga) sampel, penambahan $12 \%$ ada 3 ( tiga) sampel dan penambahan $15 \%$ ada 3 (tiga) sampel, sehingga total keseluruhan benda uji yang diperlukan berjumlah 12 (dua belas) sampel ( SNI 03-4431-1997). Penelitian ini menguji coba kekuatan kuat lentur menggunakan bahan tambahan limbah aspal. Pencampuran beton aspal yang diuji cobakan dapat digunakan dengan maksimal karena dengan memanfaatkan limbah/sisa praktikum dan penelitian tugas akhir mahasiswa yang menggunakan material aspal.

\section{METODE}

Skema bagan alir penelitian beton aspal untukperkerasan lentur jalan. Dimulai dengan mengumpulkan refrensi terkait karakteristik limbah aspal. Teknik pengujian kuat tekan beton menggunkan sampel silinder ( ASTM C59-86). Metode pengujian yang digunakan dalam pengujian benda uji ialah metode pembebanan monotonik yang menggunakan sistem two poin load pada kecepatan ramp actuator konstan sebesar $0.05 \mathrm{~mm} / \mathrm{dt}$. Balok yang diperkuat dengan GFRP-S sebanyak dua buah, yang direndam pada kolam simulasi yang sudah berisi air laut, dengan umur rendaman selama 2 tahun .(Wagola.2021). Penelitian dengan judul Pengaruh Rendaman Air Laut terhadap Kapasitas Rekatan GFRP-Sheet pada Balok Beton Bertulang, hasil penelitian menunjukkan bahwa terjadi penurunan kapasitas rekatan sekitar 11,04\% setelah perendaman selama 12 bulan (Djamaludin.2017). Pada penelitian yang lain Satu set alat uji pembebanan balok beton yang dipasangkan pada loading frame yang terdiri dari Actuator, untuk memberi beban dengan kapasitas $1500 \mathrm{kN}$, Load cell kapasitas $200 \mathrm{kN}$ untuk mengetahui besar beban yang diberikan Actuator, Phi Gauge kapasitas $3 \mathrm{~mm}$ berfungsi untuk mengukur lebar retakan ( Setiawan.2015). Pengaruh Rendaman Air Laut Terhadap Karakteristik Balok Beton Bertulang yang Diperkuat dengan Lembaran GFRP menghasilkan kuat tekan yang meningkat. ( Mufti.2014) . Sedangkan pada penelitian yang klain Pengaruh Rendaman Air Laut terhadap Kapasitas Lentur Balok yang Diperkuat dengan GFRP(Ivan.2015). Perbedaan penelitian yang sebelumnya dengan peneitian ini terletak pada material limbah aspal yang digunakan. Serta acuan metode pengujiannya. Adapun bagan air penelitian tersaji pada Gambar 1. 


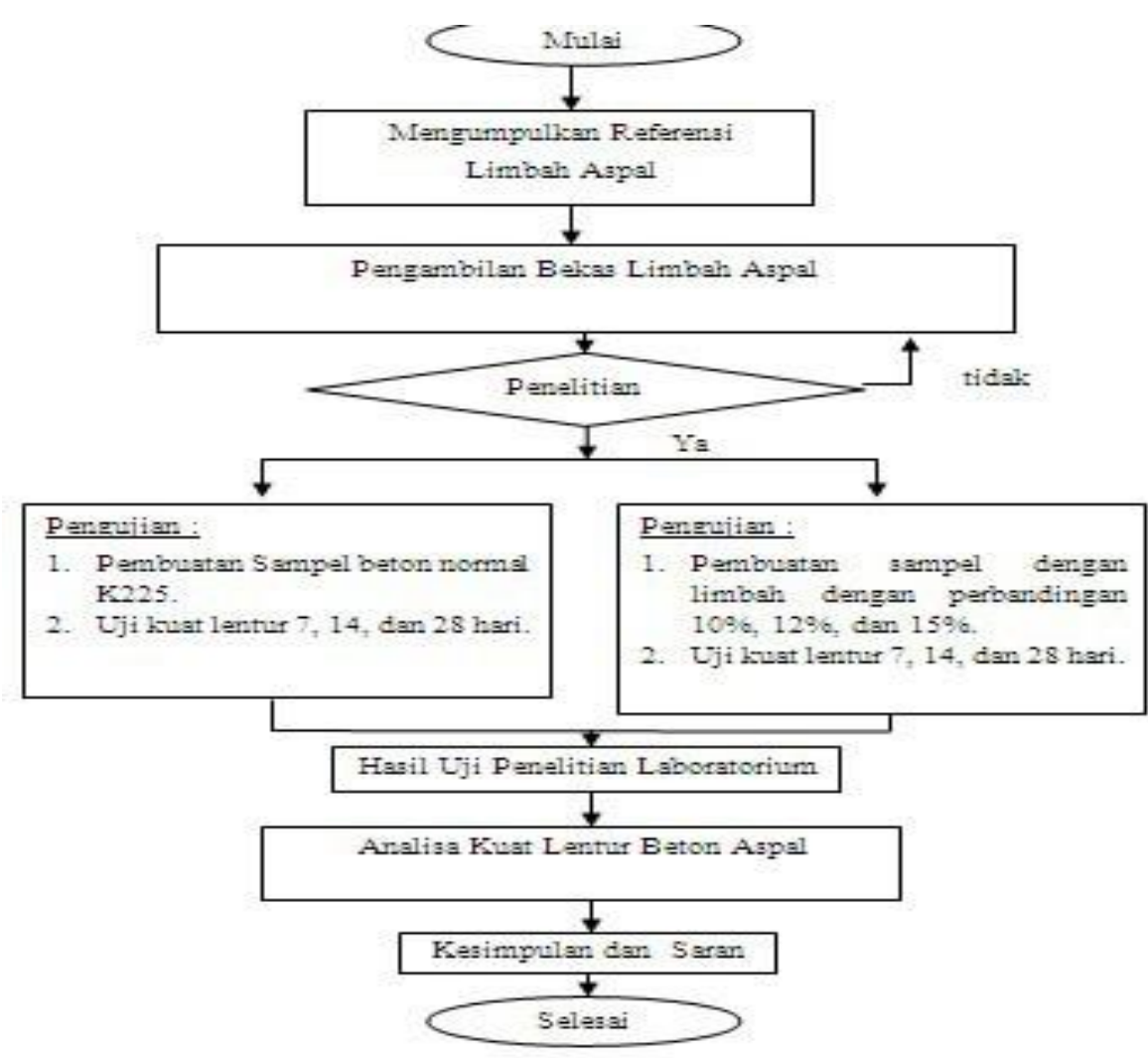

Gambar 1. Bagan Alir Penelitian

Sumber : Analisis Data Perhitungan, 2021

\section{HASIL DAN PEMBAHASAN}

Hasil Pengujian Material Semen

Pengujian material semen dilakukan di Laboratorium Bahan dan Struktur Universitas Semarang dengan menggunakan alat Vicat Appartus ( ASTM C595M-20). Hasil pengujian semen tersebut tersaji pada Gambar 2.

\begin{tabular}{|c|c|c|c|c|c|}
\hline No & $\begin{array}{l}\text { Berat Semen } \\
\text { (mam) }\end{array}$ & $\begin{array}{c}\text { Prosentase Air } \\
\text { (9v) }\end{array}$ & $\begin{array}{l}\text { Pesurunan } \\
\text { Jarum (mm) }\end{array}$ & $\begin{array}{l}\text { Sehe } \\
\text { (PC) }\end{array}$ & Keterangan \\
\hline 1 & 300 & $24 \%=72 x$ & 3.50 & $26^{\circ}$ & \multirow{4}{*}{ Stent Holcie } \\
\hline 2 & 300 & $23 \%=73 \mathrm{ml}$ & 6.00 & 270 & \\
\hline 3 & 300 & $26 \%=78 \mathrm{ml}$ & 8,80 & 270 & \\
\hline 4 & 300 & $27 \%=\$ 1 x 1$ & 14.20 & 270 & \\
\hline
\end{tabular}

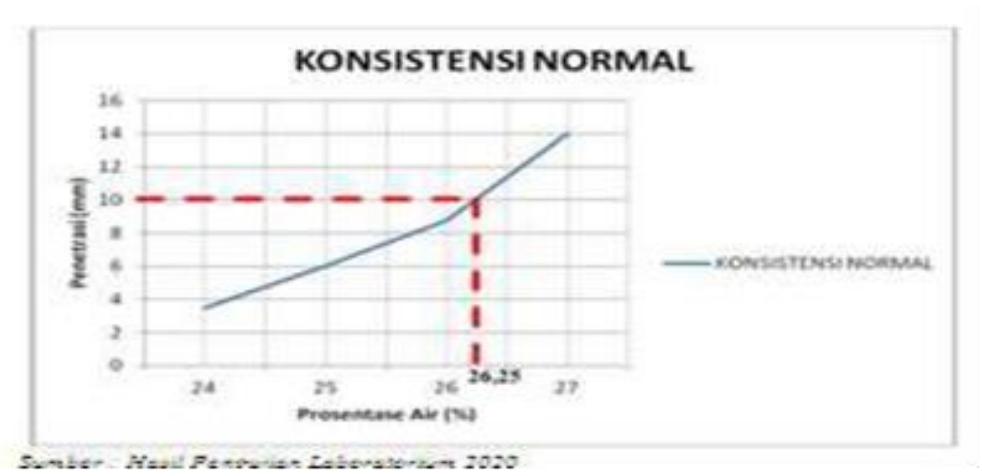




\section{Gambar 2. Pengujian Semen}

Sumber : Peneliti, 2021

Berdasarkan hasil pengujian konsistensi normal semen diperoleh kadar air optimum yang dibutuhkan dalam pengadukan semen sebesar $26.25 \%$. Semen yang dihasilkan sudah memenuhi syarat bahan material untuk campuran beton.

Hasil Pengujian Material Pasir

Hasil pengujian material pasir campuran beton bahan tambah tetes tebu diperoleh 2.69 penyerapan air $1.18 \%$ (Hartanto.2016) .Hasil pengujian material pasir yang dilakukan di Laboratorium Bahan dan Struktur Universitas Semarang menggunakan alat Absorbtion Test untuk mengetahui nilai berat jenis material pasir yang akan digunakan untuk campuran beton tersaji pada Gambar 3.

\begin{tabular}{|c|c|c|c|c|}
\hline & & $A$ & $\mathrm{~B}$ & Rata-Rara \\
\hline 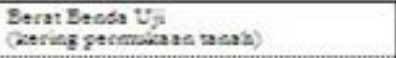 & (35D) & 200,00 & 200,00 & $\$ 00,00$ \\
\hline $\begin{array}{l}\text { Berat Beosa U; } \\
\text { (ceriag evea) }\end{array}$ & (Ex) & 495.20 & $495: 50$ & 493,40 \\
\hline $\begin{array}{l}\text { Strat Pincosentes Siat Air } \\
25^{\circ} \mathrm{C}\end{array}$ & (B) & 682,20 & 680,90 & 832,00 \\
\hline $\begin{array}{l}\text { Beras Pinsonaterr - Bevda } \mathrm{C}_{j i} \mathrm{~S} \mathrm{D} \text { - } \\
\text { Air } 25^{\circ} \mathrm{C}\end{array}$ & (Br) & 945,50 & 947.30 & 945,65 \\
\hline
\end{tabular}

\begin{tabular}{|c|c|c|c|c|c|}
\hline & & & A & B & Rata-Rata \\
\hline Secas tesiat & (Ettk) & $\frac{B K}{(B-500-B t)}$ & 2.55 & 2.57 & 2.55 \\
\hline 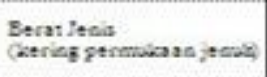 & $(350)$ & $\frac{500}{(B-500-B t)}$ & 2.49 & 2.70 & 270 \\
\hline Berat Denia Semb & CAssacnet & $\frac{B K}{(B-B K-B t)}$ & $2:-7$ & 2.75 & 2.79 \\
\hline Fisptosac (atuedtiev) & & $\frac{(500-B K)}{B K} \cdot 10096$ & 2.25 & 2.22 & 2.34 \\
\hline
\end{tabular}

Gambar 3. Pengujian Berat Jenis Pasir

Sumber : Peneliti, 2021

Berdasarkan hasil pengujian berat jenis agregat halus diperoleh nilai berat jenis pasir sebesar 2.7 dan penyerapan air sebesar $1.34 \%$. Agregat halus memenuhi standart minimal bahan material yang lolos spefisifikasi material campuran beton.

\section{Hasil Pengujian Material Kerikil}

Hasil pengujian material kerikil yang dilakukan di Laboratorium menggunakan alat Spesific Gravity untuk mengetahui nilai berat jenis material pasir yang akan digunakan untuk campuran beton (Fanto,dkk.2015). Hasil pengujian material tersaji pada Gambar 4. 


\begin{tabular}{|c|c|c|c|c|}
\hline & & $\lambda$ & B & Ratn-Reta \\
\hline 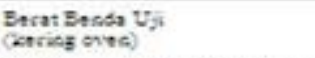 & (BK) & 9775,00 & 5765,00 & 2771,20 \\
\hline 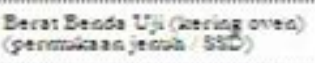 & (ES) & 3505,00 & $\$ \$ 01,00$ & $590+50$ \\
\hline 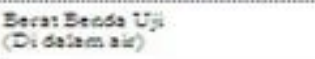 & (BA) & 3545,00 & 3521,00 & 3583.00 \\
\hline
\end{tabular}

\begin{tabular}{|c|c|c|c|c|c|}
\hline & & & A & 8 & Rara-Rata \\
\hline Derar Decis & (EutK) & $\frac{B K}{(B U-B d)}$ & 2.58 & 2.5 & 2.50 \\
\hline 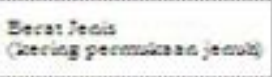 & (950) & $\frac{B V}{(B V-B . d)}$ & 2.57 & 2,55 & 2.52 \\
\hline Decas tecis Stems & (Appatede) & $\frac{B K}{(B R-B d)}$ & 2.59 & 2.89 & 2.54 \\
\hline 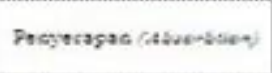 & & $\frac{(B V-B K)}{B K}+10096$ & $0: 52$ & 0.52 & 0.57 \\
\hline
\end{tabular}

\section{Gambar 4. Pengujian Berat Jenis Kerikil}

Sumber : Peneliti, 2021

Berdasarkan hasil pengujian berat jenis agregat kasar diperoleh nilai berat jenis pasir sebesar 2.64 dan penyerapan air sebesar $0.57 \%$. Agregat halus memenuhi standart minimal bahan material yang lolos spefisifikasi material campuran beton.

Hasil pengujian lentur

Hasil pengujian kuat lentur beton yang dilakukan di Laboratorium menggunakan alat Flexsure Beam dengan kapasitas $100 \mathrm{KN}$ ( SNI 03-4431-1997).Variasi penambahan limbah aspal pada sampel balok dengan persentase $10 \%, 12 \%, 15 \%$ serta balok normal sebanyak 12 sampel tersaji pada Gambar 5 .

\begin{tabular}{|c|c|c|c|c|c|c|c|c|c|c|c|}
\hline Rint: & 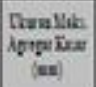 & (na) & $\begin{array}{l}\text { Suly } \\
\text { tarr } \\
\text { Mey }\end{array}$ & 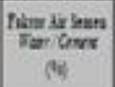 & 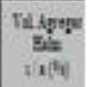 & rati: & 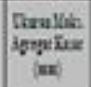 & (an) & $\begin{array}{l}\text { Babr } \\
\text { ther } \\
\text { Bar }\end{array}$ & 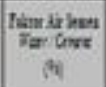 & 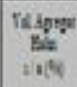 \\
\hline 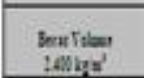 & $\frac{17}{3 x^{2}}$ & $\begin{array}{c}x \\
y=\end{array}$ & $\lim ^{2}$ & \multirow[t]{2}{*}{$\begin{array}{l}\text { Thin } \\
\text { tyah }\end{array}$} & \multirow{2}{*}{ 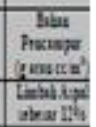 } & 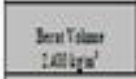 & $\begin{array}{c}\mathrm{k} \\
\mathrm{ag} \mathrm{a}^{3}\end{array}$ & $\begin{array}{c}k \\
\left(\mathrm{y}^{2}\right)\end{array}$ & $\begin{array}{l}\text { hàे } \\
\left(\mathrm{ge}^{\prime}\right)\end{array}$ & \multirow[t]{2}{*}{$\begin{array}{l}\text { fell } \\
\text { (tyit) }\end{array}$} & \multirow{2}{*}{ 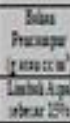 } \\
\hline & & & & & & & & & & & \\
\hline Susulatis 5 & \begin{tabular}{|l} 
Intiabia \\
Aquille
\end{tabular} & \begin{tabular}{|l|} 
Lentikent \\
Aquithen
\end{tabular} & 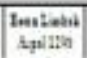 & & & Shenteda 5 & 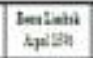 & 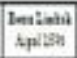 & 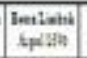 & & \\
\hline Find: & $\mathrm{xit}$ & ma & au & & & $\begin{array}{l}\text { vian: } \\
\text { te }\end{array}$ & 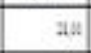 & aw. & a.: & & \\
\hline $\begin{array}{l}\text { Sidakin } \\
\text { m }\end{array}$ & 1ReA & LEM & Atim & & & tarthes & $\pm 4 x$ & tant & wh: & & \\
\hline Syinthy & athes & t362 & IRu & & & 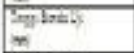 & the & saw & thal & & \\
\hline किसानी & mas & $\operatorname{tas}$ & $\mathrm{sut}$ & & & 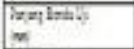 & 대네 & 른 & wa. & & \\
\hline $\begin{array}{l}\text { Inthes } \\
\text { it }\end{array}$ & : $1 \mathrm{x}$ & 328 & 24 & & & \begin{tabular}{|l|}
$\operatorname{Int}$ ien: \\
ig \\
\end{tabular} & $3 \%$ & 21: & 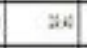 & & \\
\hline किजा & un & tat & in & & & 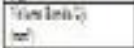 & \pm 18 & ast & $a s$ & & \\
\hline 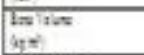 & 20 & $23 t$ & 211 & & & 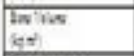 & $v$ & 24 & $\therefore$ & & \\
\hline Then & Fanst & sament & fsusto & & & thatisn & atus & Inati & mais & & \\
\hline का & Antat & $\operatorname{sen} x$ & सew & & & $\begin{array}{l}\text { ming } \\
m^{2}\end{array}$ & $\Delta x$ & sea & 4n: & & \\
\hline 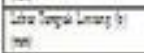 & ARu & then & and & & & $\begin{array}{l}\text { Animathis } \\
m\end{array}$ & $24 x$ & :atu & the & & \\
\hline 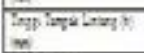 & inat & that & and & & & 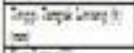 & tath & aㅐㅅㅐ & $\pm n$ & & \\
\hline 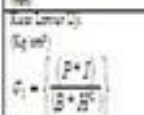 & $H^{\circ}$ & "Ii & if & & & 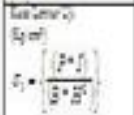 & $4 \%$ & $u^{\circ}$ & $*$ & & \\
\hline
\end{tabular}

Gambar 5. Pengujian Kuat Lentur Beton 
Sumber: Analisis Pengujian Laboratorium, 2021

\section{SIMPULAN}

Beton normal kuat lentur sebesar $12 \mathrm{Mpa}$,Pada penambahan limbah aspal 10\% nilai kuat lentur sebesar 13,30 Mpa. Limbah aspal 12\% nilai kuat lentur $=7,60 \mathrm{Mpa}$. Limbah aspal 15\% nilai kuat lentur $=5,00 \mathrm{Mpa}$.Untuk mendapatkan kuat lentur yang optimal, penambahan limbah aspal sebesar 10 $\%$.Semakin besar penambahan limbah aspal, kuat lentur karakteristik semakin kecil.

\section{DAFTAR PUSTAKA}

Akmalia dan Izati. 2018."Kuat Tekan Beton dengan Limbah Bulu Ayam.

Annual Book of ASTM C595M-20 Standard Specification for Blended Hydraulic Cements sulfate resistance portland cement clinkers.

Annual Book of ASTM Standards, 2002, ASTM C39-86 Standard Test Method for Compressive Strength of Cylindrical Concrete Specimens

Asrullah.2019."Kajian Kuat Lentur Beton Dengan Menggunakan Sika Concrete Refair Mortar Sebagai Pengganti Semen Pada Campuran Beton K 300. Jurnal Teknik Sipil Universitas Palembang.

Fanto.dkk.2015. "Pengujian Kuat Tarik Lentur Beton Dengan Variasi Kuat Tekan Beton. Jurnal Sipil Statik. Universitas San Ratulangi Manado

Hartanto.2016.Pengaruh Variasi Konsentrasi Limbah Tetes Tebu Terhadap Kuat Tekan Beton, Jurnal Teknik Universitas Muhamadiyah Surakarta.

Leonardus,dkk.2019. "Pemeriksaan Kuat Tekan dan Kuat Tarik Lentur Beton Serat Kawat Bendrat yang ditekuk dengan Variasi Sudut Berbeda. Jurnal Sipil Statik ,Universitas San Ratulangi Manado.

Mulyono, 2014. "Dari Teori ke Praktek" Universitas Negeri Jakarta.

SNI 03-4431-1997. Metode Kuat Lentur Normal dengan Dua Titik Pembebanan.

Yasa dan Wati.2015. Pengaruh Kuat tekan beton dengan menggunakan Serat Nanas. Jurnal Teknik Universitas Lancang Kuning.

Djamaluddin, R., Mufti Amir. 2017. Pengaruh Rendaman Air Laut terhadap Kapasitas Rekatan GFRP-Sheet pada Balok Beton Bertulang. Jurnal Teoretis dan Terapan Bidang Rekayasa Sipil, Vol. 24 No. 1

Wagola.2021.Analisis Kapasitas Lentur Balok Beton Bertulang Dengan Perkuatan GFRP Setelah Direndam Dalam Air Laut. Journal of Science and Technology

Rangan, Ivan. 2015. Pengaruh Rendaman Air Laut terhadap Kapasitas Lentur Balok yang Diperkuat dengan GFRP.

Setiawan, Asri M. 2015. Pengaruh Air Laut Terhadap Kuat Lentur Balok Beton Bertulang dengan Perkuatan GFRP-S yang Direndam Selama SatuTahun.

Sultan, Mufti A., dkk. 2014. Pengaruh Rendaman Air Laut Terhadap Karakteristik Balok Beton Bertulang yang Diperkuat dengan Lembaran GFRP. 